\title{
Inhibition of Alpha-Glucosidase and Antioxidant Test of Stem Bark Extracts of Garcinia fruticosa Lauterb
}

\author{
Nusaibah Zahratunnisa, Berna Elya*, Arikadia Noviani
}

\section{Nusaibah Zahratunnisa, Berna Elya*, Arikadia Noviani \\ Department of Pharmacognosy- Phytochemistry, Faculty of Pharmacy, Universitas Indonesia, Kampus Baru UI Depok, 16424, Depok, INDONESIA.}

\section{Correspondence}

\section{Berna Elya}

Faculty of Pharmacy, Universitas Indonesia, Gedung A Rumpun IImu Kesehatan Lantai 1, Kampus UI, Depok, Jawa Barat - 16424, INDONESIA.

Phone: +62 217270031

E-mail: berna.elya@gmail.com

\section{History}

- Submission Date: 21-12-2016

- Review completed: 05-01-2017;

- Accepted Date: 16-01-2017.

\section{DOI : 10.5530/pj.2017.2.46}

Article Available online http://www.phcogj.com/v9/i2s

\section{Copyright}

(C) 2017 Phcog.Net. This is an openaccess article distributed under the terms of the Creative Commons Attribution 4.0 International license.

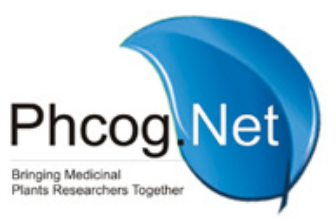

\begin{abstract}
Introduction: Diabetes mellitus (DM) is one of the global health emergencies that characterized by high blood glucose levels (hyperglycemia). Type $2 \mathrm{DM}$ is the most common type in diabetic populations. Inhibition of alphaglucosidase can ameliorate postprandial hyperglycemia that occurs in patients with type $2 \mathrm{DM}$. Adding antioxidants to the therapy of DM is intended to reduce complications caused by oxidative stress. Some species of Garcinia have been proven to inhibit alpha-glucosidase and have antioxidant activity, but there is no research on Garcinia fruticosa Lauterb. Therefore, the aims of this research were to determine the activity of Garcinia fruticosa Lauterb. stem bark in inhibiting alpha-glucosidase and as an antioxidant. Methods: In this research, the Garcinia fruticosa Lauterb. stem bark was dried, grinded, and extracted by multistage maceration using n-hexane, ethyl acetate, and methanol. Inhibition of alpha-glucosidase test has been done in vitro on concentrated extracts and measured by microplate reader at $400 \mathrm{~nm}$. The antioxidant test has been done using DPPH scavenging method and was measured by microplate reader at $519 \mathrm{~nm}$. Results: Ethyl acetate extract is the most active extract for both test. $I C_{50}$ values for inhibition of alpha-glucosidase test are $20.18 \mu \mathrm{g} / \mathrm{mL}$ that is more active than standard (acarbose) which has $I_{50}$ value $141.55 \mu \mathrm{g} / \mathrm{mL}$. Meanwhile, $I C_{50}$ value from an antioxidant test is $8.93 \mu \mathrm{g} / \mathrm{mL}$ that is not more active than standard (quercetin) which has $I C_{50}$ value $2.51 \mu \mathrm{g} / \mathrm{mL}$. Conclusion: Phytochemical screening shows that the ethyl acetate extract contains alkaloids, flavonoids, glycosides, saponins, and tannins.
\end{abstract}

Key words: Alpha-glucosidase, Antioxidant, DPPH, Garcinia fruticosa Lauterb. Stem bark, Phytochemical screening.

\section{INTRODUCTION}

Diabetes mellitus (DM) is one of the leading causes of death and disability in worldwide. ${ }^{1} \mathrm{DM}$ is characterized by hyperglycemia caused by abnormalities in insulin secretion, insulin action, or both. Prevalence of DM increase annually. ${ }^{2}$ Inhibition of alpha-glucosidase enzyme is one of the antidiabetic mechanism that uses in DM therapy, for example, acarbose. This mechanism can inhibit glucose absorption so can prevent hyperglycemia. ${ }^{3}$ As a single therapy, acarbose is less effective because it is only $2 \%$ absorbed. ${ }^{4}$ Chronic hyperglycemia can cause many complications such as damage, dysfunction and failure of various organs, especially the eyes, kidneys, nerves, heart, and blood vessels. ${ }^{1}$ Hyperglycemia has an important contribution in causing complications because of the trigger in free radicals reaction. ${ }^{5}$ Adding antioxidants in the DM therapy may prevent oxidative stress that caused by free radicals so that complications can be prevented. ${ }^{6}$

There are many kinds of research on species of Garcinia about their activity as alpha-glucosidase inhibitors and antioxidants but there is no research on Garcinia fruticosa Lauterb. Ethanolic extract of $G$. daedalanthera Pierre. stem barks showed that the extract can inhibit $\alpha$-glucosidase with $\mathrm{IC}_{50}$ value 3.71 $\mu \mathrm{g} / \mathrm{ml}^{7}{ }^{7}$ Besides that, methanolic extract of G. lateriflora Blume varJavanica Boerlleaves showed that the extract has antioxidant activity using DPPH (2,2-diphenyl-1-picrylhydrazyl) scavenging method with $\mathrm{IC}_{50}$ value $6.18 \mu \mathrm{g} / \mathrm{ml} .{ }^{8}$ Based on chemotaxonomic consideration, Garcinia fruticosa Lauterb. could be expected to inhibit alpha-glucosidase and has antioxidant activity so could be used as a DM therapy.

\section{MATERIALS AND METHODS}

\section{Plant Material}

The stem bark of Garcinia fruticosa Lauterb. was collected in January 2016 from Bogor, Indonesia and identified by Center for Plant Conservation-Bogor Botanical Garden.

\section{Extraction}

The dried stem bark of Garcinia fruticosa Lauterb. (780 g) was powdered and extracted consecutively with n-hexane, ethyl acetate, and methanol by cold maceration and then evaporated. On each extract is performed inhibition of alpha-glucosidase test and antioxidant test using DPPH scavenging method.

Inhibition of Alpha-Glucosidase Test 
The inhibition of alpha-glucosidase was determined using adopted method. ${ }^{9}$ Five mg (equivalent to 90.3 units alpha-glucosidase enzyme) of alpha-glucosidase (Saccharomyces cerevisiae, Sigma-Aldrich, Germany) was dissolved in 50,0mL of phosphate buffer ( $\mathrm{pH} 6.8$ ) containing 100 $\mathrm{mg}$ of bovine serum albumin (Sigma-Aldrich, USA) and then diluted $152 \mu \mathrm{L}$ in $5,0 \mathrm{~mL}$ with phosphate buffer ( $\mathrm{pH} 6.8$ ). The reaction mixture consisting $30 \mu \mathrm{L}$ of samples at varying concentrations was premixed with $36 \mu$ Lphosphate buffer $\mathrm{pH} 6.8$ and $17 \mu \mathrm{L}$ of $5 \mathrm{mMp}$-nitrophenyl$\alpha$-D-glucopyranoside (Sigma-Aldrich, Switzerland). After preincubating at $39^{\circ} \mathrm{C}$ for $5 \mathrm{~min}, 17 \mu$ Lalpha-glucosidase $(0.045 \mathrm{units} / \mathrm{mL})$ was added and incubated at $39^{\circ} \mathrm{C}$ for 15 minutes. The reaction was terminated by adding $100 \mu \mathrm{LNa}_{2} \mathrm{CO}_{3} 200 \mathrm{mM}$. Inhibition of alpha-glucosidase was determined at $400 \mathrm{~nm}$ using microplate reader (Versamax ELISA Microplate Reader, USA) by measuring the quantity of p-nitrophenol released from p-NPG. Acarbose was used as positive control of $\alpha$-glucosidase inhibitor. The concentration of the extract required to inhibit $50 \%$ of $\alpha$-glucosidase activity under the assay conditions was defined as the $\mathrm{IC}_{50}$ value.

\section{Antioxidant Activity Test}

The DPPH scavenging method was adopted from Bobo-Garcia et al..$^{10}$ The preliminary antioxidant test was done using n-hexane extract, ethyl acetate extract, and methanol extract with same concentration $(100 \mu \mathrm{g} /$ $\mathrm{mL}$ ). The $\mathrm{IC}_{50}$ value was determined on the most active extract. The reaction mixture consisting $20 \mu \mathrm{L}$ of diluted samples at varying concentrations was added to $180 \mu \mathrm{L}$ of DPPH solution $(150 \mu \mathrm{mol} / \mathrm{L})$ in methanolwater $(80: 20, \mathrm{v} / \mathrm{v})$ and shaken for 60 seconds in a 96-well microplate. After 40 minutes in the dark at room temperature, the absorbance was measured at $519 \mathrm{~nm}$ in the microplate reader of Versamax ELISA Microplate Reader (USA). Quercetin was used as a standard at $1.5-3.5 \mu \mathrm{g} / \mathrm{mL}$. The \% DPPH quenched was calculated using:

$$
\% \text { DPPH quenched }=\left[1-\left(\frac{A_{\text {sample }}-A_{\text {blanko }}}{A_{\text {control }}-A_{\text {blank }}}\right)\right] \times 100
$$

where A sample is the absorbance at $519 \mathrm{~nm}$ of $20 \mu \mathrm{L}$ of extract or standard with $180 \mu \mathrm{L}$ DPPH solution after 40min; A blank is an absorbance at $519 \mathrm{~nm}$ of $20 \mu \mathrm{L}$ of water with $180 \mu \mathrm{L}$ methanol-water $(80: 20, v / v)$ after $40 \mathrm{~min}$, and Controls the absorbance at $519 \mathrm{~nm}$ of $20 \mu \mathrm{L}$ of water with $180 \mu \mathrm{L}$ DPPH solution after $40 \mathrm{~min}$.

\section{Phytochemical Screening}

Phytochemical screening was performed to determine alkaloid using Mayer, Dragendorff, and Bouchardartreagents; flavonoid using Shinoda Test; glycoside using Molisch reaction; terpenoids using LiebermannBurchard reaction; tannin using ferrous (III) chloride and $\mathrm{Pb}$ (II) acetate; saponin with honeycomb froth test; and anthraquinone with Borntrager test.

\section{RESULTS AND DISCUSSION}

\section{Inhibition of Alpha-Glucosidase Test}

Inhibition of alpha-glucosidase test was performed in optimal conditions for the enzyme that have been optimized. The optimal conditions include $\mathrm{pH} 6.8$, temperature $39^{\circ} \mathrm{C}$, enzyme concentration $0.045 \mathrm{U} /$ $\mathrm{mL}$, and substrate concentration $5 \mathrm{mM}$. This test use microplate reader (Versamax ELISA Microplate Reader) at $400 \mathrm{~nm}$. Acarbose is used as a standard. The result shows that acarbose has high IC50 value $141.55 \mu \mathrm{g} /$ $\mathrm{mL}$. This test was performed on all of the extracts with various concentrations. The results show that $\mathrm{IC}_{50}$ value for $\mathrm{n}$-hexane extract is 643.20 $\mu \mathrm{g} / \mathrm{mL} ; \mathrm{IC}_{50}$ value for ethyl acetate extract is $20.18 \mu \mathrm{g} / \mathrm{mL}$; and $\mathrm{IC}_{50}$ value for methanol extract is $48.88 \mu \mathrm{g} / \mathrm{mL}$ (Table 1). $\mathrm{IC}_{50}$ value ethyl acetate and methanol extract lower than acarbose. That means ethyl acetate and methanol extract is better in inhibiting alpha-glucosidase than acarbose. The ethyl acetate extract is the most active extract in this test because it has the lowest $\mathrm{IC}_{50}$ value. This result is related to chemical compounds in the extract that can inhibit alpha-glucosidase synergistically, in contrast to acarbose which is a single compound.

\section{Antioxidant Activity Test}

The antioxidant test was performed using DPPH scavenging method by microplate reader (Versamax ELISA Microplate Reader, USA) at 519 $\mathrm{nm}$ that was the maximum wavelength of DPPH. Quercetin is used as a standard. The result of the antioxidant test for quercetin showed that quercetin has antioxidant activity with $\mathrm{IC}_{50} 2.51 \mu \mathrm{g} / \mathrm{mL}$. Preliminary antioxidant test for extracts was done using n-hexane extract, ethyl acetate extract, and methanol extract with same concentration $(100 \mu \mathrm{g} /$ $\mathrm{mL})$.The $\mathrm{n}$-Hexane extract has percent DPPH quenched $17.53 \%$, ethyl acetate extract has $46,52 \%$, and methanol extract has $35,98 \%$ (Table 2). Therefore, the most active extract in having antioxidant activity is ethyl acetate extract because it has the highest percent DPPH quenched. This extract was performed to determine $\mathrm{IC}_{50}$ value. The result shows that the ethyl acetate extract has $\mathrm{IC}_{50} 8.93 \mu \mathrm{g} / \mathrm{mL}$. IC I0 $_{50}$ value extract is higher than standard (quercetin). In the other words, the extract is not more active than quercetin. However, based on Blois classification the extract is a very strong antioxidant because of the $\mathrm{IC}_{50}$ value lower than $50 \mu \mathrm{g} / \mathrm{mL}$. The strong antioxidant activity is related to phenolic and flavonoid compounds contained in extracts. ${ }^{11}$

\section{Phytochemical Screening}

The screening was done on the most active extract in both inhibitions of alpha-glucosidase test and antioxidant activity test that is ethyl acetate extract. The results from phytochemical screening show that the extract contains alkaloids, flavonoids, glycosides, tannins, and saponins (Table 3). Alkaloids are discovered can inhibit the alpha-glucosidase activity competitively and non-competitively. ${ }^{12}$ Flavonoids can inhibit alpha-glucosidase activity and have antioxidant activity because of the hydroxyl groups. ${ }^{13,14}$ Glycosides also have a role in inhibiting alpha-glucosidase because of the similar structure substrate (contains glucose) so that glycosides can bind to active site. ${ }^{7}$ Tannins have a role in inhibiting alphaglucosidase because those can bind to protein make complexes. ${ }^{15}$ The hydroxyl groups in tannins have roles in inhibiting alpha-glucosidase and antioxidant activity. ${ }^{8,12}$

Table 1: Inhibition of alpha-glucosidase results

\begin{tabular}{cc}
\hline Sample & $\mathrm{IC}_{50}(\mu \mathrm{g} / \mathrm{mL})$ \\
\hline Acarbose & 141.55 \\
n-Hexane Extract & 643.20 \\
Ethyl Acetate Extract & 20.18 \\
Methanol Extract & 48.88 \\
\hline
\end{tabular}

Table 2: Antioxidant activity results

\begin{tabular}{ccc}
\hline Sample & \% DPPH quenched & $\mathrm{IC}_{50}(\mu \mathrm{g} / \mathrm{mL})$ \\
\hline Quercetin & - & 2.51 \\
n-Hexane Extract & 17.53 & - \\
Ethyl Acetate Extract & 46.52 & 8.93 \\
Methanol Extract & 35.98 & - \\
\hline
\end{tabular}


Table 3: Phytochemical screening results

\begin{tabular}{cc}
\hline Phytochemical Contents & Results \\
\hline Alkaloid & + \\
Flavonoid & + \\
Glycoside & + \\
Terpenoid & - \\
Tannin & + \\
Saponin & + \\
Anthraquinone & - \\
\hline
\end{tabular}

\section{CONCLUSION}

Ethyl acetate extract is the most active extract in inhibiting alpha-glucosidase ( $\mathrm{IC}_{50} 20.18 \mu \mathrm{g} / \mathrm{mL}$ ) and as antioxidant ( $\mathrm{IC}_{50} 8.93 \mu \mathrm{g} / \mathrm{mL}$ ). Phytochemical screening shows that the extract contains alkaloids, flavonoids, glycosides, saponins, and tannins.

\section{ACKNOWLEDGEMENT}

Thanks to PITTA Grant that funding this research

\section{CONFLICT OF INTEREST}

None

\section{REFERENCES}

1. Matough FA, Budin SB, Hamid ZA, Alwahaibi N, Mohamed J. The Role of Oxidative Stress and Antioxidants in Diabetic Complications. SQU Medical Journal. 2012;12(1):5-18

2. International Diabetes Federation. IDF Diabetes Atlas. 2015

3. Van de Laar FA. Alpha-glucosidase inhibitors in the early treatment of type 2 diabetes. Vascular Health and Risk Management. 2008;4(6):1189-95. https://doi. org/10.2147NHRM.S3119 PMid:19337532 PMCid:PMC2663450.

4. Bösenberg L, van Zyl D.G. The mechanism of action of oral antidiabetic drugs: A review of recent literature. Journal of Endocrinology Metabolism and Diabetes of South Africa. 2008;13(3):80-8. https://doi.org/10.1080/22201009.2008.10872 177.

5. Stadler K. Oxidative stress in diabetes. In Diabetes (pp. 272-287). Springer New York. 2013 https://doi.org/10.1007/978-1-4614-5441-0_21.

6. Dewi RT, Maryani F. Antioxidant and $\alpha$-Glucosidase Inhibitory Compounds of Centella asiatica. Procedia Chemistry. 2015;17:147-52. https://doi.org/10.1016/j. proche.2015.12.130

7. Elya B, Basah K, Mun'im A, Yuliastuti W, Bangun A, Septiana EK. Screening of $\alpha$ -Glucosidase Inhibitory Activity from Some Plants of Apocynaceae, Clusiaceae Euphorbiaceae, and Rubiaceae. Journal of Biomedicine and Biotechnology, 2012. http://doi.org/10.1155/2012/281078 https://doi.org/10.1155/2012/281078.

8. Elya B, Katrin B, Mun'im A, Hasiholan A, Marlin I, Mailandari M. Antioxidant activities of leaves extracts of three species of Garcinia. Int J Med Arom Plants. 2012;2(4):691-3

9. Fadhilah R. Uji Efek Antidiabetes dengan Metode Uji Penghambatan Aktivitas Alfa-Amilase dan Alfa-Glukosidase, serta Penapisan Fitokimia dari Daun Garcinia kydia Roxb. 2015

10. Bobo-García G, Davidov-Pardo G, Arroqui C, Vírseda P, Marín-Arroyo MR, Navarro M. Intra-laboratory validation of microplate methods for total phenolic content and antioxidant activity on polyphenolic extracts, and comparison with conventional spectrophotometric methods. Journal of the Science of Food and Agriculture. 2015;95(1):204-9. https://doi.org/10.1002/jsfa.6706 PMid:24756821.

11. Fidrianny I, Aristya T, Hartati R. Antioxidant Capacities of Various Leaves Extracts from Three Species of Legumes and Correlation with Total Flavonoid, Phenolic, Carotenoid Content. International Journal of Pharmacognosy and Phytochemical Research. 2015;7(3):628-34.

12. Zhenhua $Y$, Wei Z, Fajin F, Yong Z, Wenyi K. $\alpha$-Glucosidase inhibitors isolated from medicinal plants. Food Science and Human Wellness. 2014;3(3):136-74.

13. Tadera K, Minami Y, Takamatsu K, Matsuoka T. Inhibition of alpha-glucosidase and alpha-amylase by flavonoids. Journal of Nutritional Science and Vitaminology. 2006;52(2):149-153. http://doi.org/10.3177/jnsv.52.149 https://doi. org/10.3177/jnsv.52.149.

14. Hamid AA, Aiyelaagbe OO, Usman LA, Ameen OM, Lawal A. Antioxidants : Its medicinal and pharmacological applications. African Journal of Pure and Applied Chemistry. 2010;4(8):142-51.

15. Saxena M, Saxena J, Nema R, Singh D, Gupta A. Phytochemistry of Medicinal Plants. Journal of Pharmacognosy and Phytochemistry Phytochemistry. 2013;1(6):168-82.

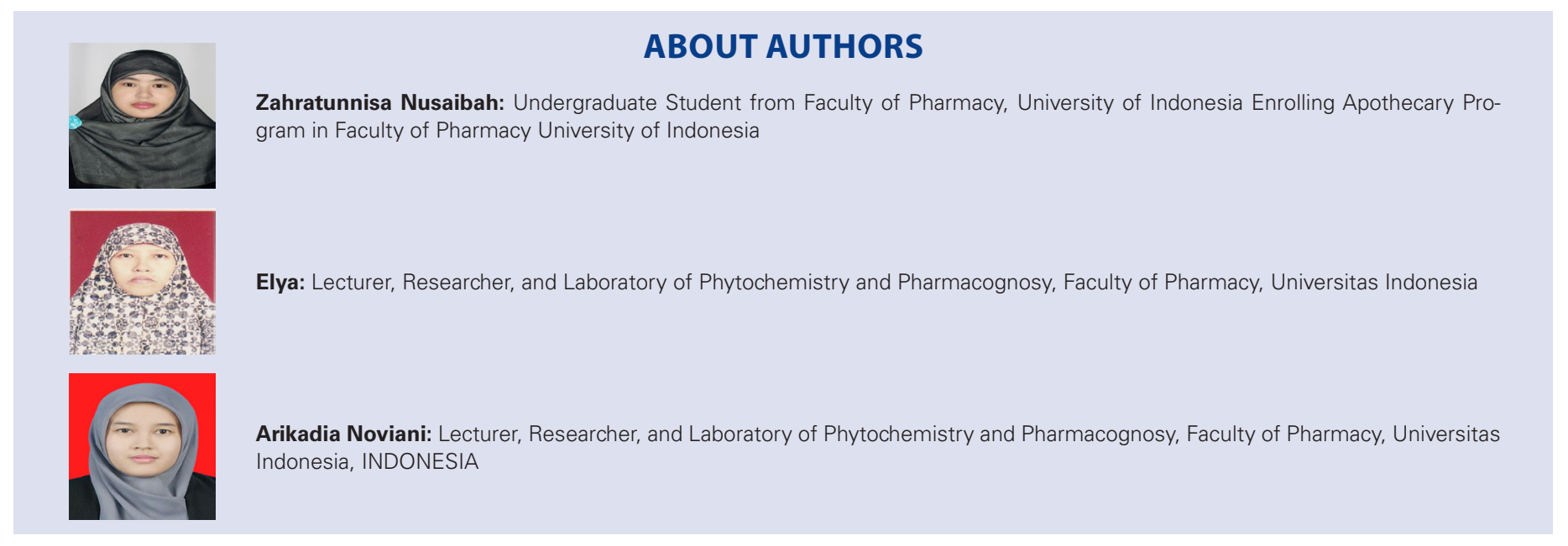

Cite this Article: Zahratunnisa N, Elya B, Noviani A. Inhibition of Alpha-Glucosidase and Antioxidant Test of Stem Bark Extracts of Garcinia fruticosa Lauterb. Pharmacogn J. 2017;9(2):273-5. 